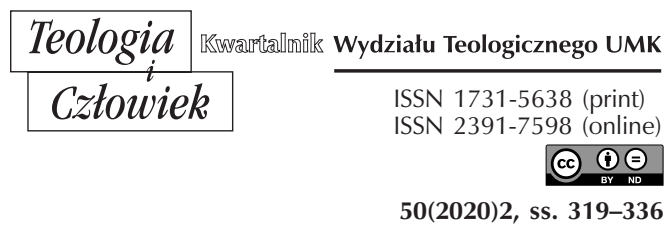

KS. ZBIGNIEW ZAREMBSKI

UNIWERSYTET MIKOŁAJA KOPERNIKA W TORUNIU

ZZAREMB@UMK.PL

ORCID 0000-0002-4506-2956

\title{
UCZESTNICTWO RODZINY KATOLICKIEJ W ROZWOJU SPOŁECZEŃSTWA
}

DOI: http://dx.doi.org/10.12775/TiCz.2020.030

Streszczenie. Rodzina jest społecznością powołaną do wzbudzania i rozwoju życia jednostkowego a także społecznego. Nauczanie Kościoła ujmuje rodzinę jako wspólnotę i instytucję. Św. Jan Paweł II podkreślał, że rodzina jest pierwszą i żywotną komórką społeczeństwa. W oparciu więc o nauczanie Kościoła i literaturę przedmiotu Autor artykułu wyjaśnia co rodzina wnosi do społeczeństwa i jednocześnie pokazuje na czym polega socjalizacja w rodzinie. Szczególna rola rodziny w procesie socjalizacji wynika $\mathrm{z}$ faktu, że jest ona chronologicznie pierwszą a zarazem najważniejszą wspólnotą w życiu człowieka. Jest ona przy tym pomostem pomiędzy jednostką a społeczeństwem. W artykule ukazane zostały także różne rodzaje powiązań jakie powstają pomiędzy społeczeństwem i rodziną, które wyraźnie wskazują, że to dzięki rodzinie młode pokolenie zostaje wprowadzone do społeczeństwa. Omówiono wkład społeczeństwa w funkcjonowanie rodziny, podstawowe prawa, przynależące rodzinie $\mathrm{z}$ racji jej powołania i misji a w ostatniej części publikacji zaprezentowano w sposób syntetyczny jak po 1989 roku kształtowała się w Polsce polityka prorodzinna.

Słowa kluczowe: rodzina; społeczeństwo; socjalizacja; prawa rodziny; polityka prorodzinna.

Abstract. Participation of a Catholic family in the development of the socjety. The family is a community called to awaken and develop an individual as well as social 
life. The teaching of the Church embraces the family both as a community and institution.

St. John Paul II emphasized in his teaching that the family was the first and vital cell of the society. Hence, the author, in his publication, referring to papal teaching, presented the participation of the family in the life of the society. Basing on the Church teaching as well as on the subject literature he explained in which way the family contributed to society and showed what socialization in family consisted on. The special role of the family in this process is due to the fact that chronologically, it is the first and the most important community in human life. It means that one can see it as the bridge between the individual and society. The article also shows the various types of relationships that emerge between society and the family, indicating that it is thanks to the family that the young generation is introduced to society. The article also discusses the society's contribution to the functioning of the family, its basic rights because of its calling and mission. The last part of the publication presents how pro-family policy developed in Poland after 1989.

Key words: family; socjety; socialization; family rights; family policy.

Rodzina jest społecznością powołaną do wzbudzania i rozwoju życia jednostkowego a jednocześnie stanowi podstawę życia społecznego. Nauczanie Kościoła ujmuje rodzinę jako wspólnotę osób i instytucję. Wspólnotowy charakter rodziny wyraża się w tym, że jest ona „wspólnotą miłości i solidarności”, miejscem najbardziej głębokiego a także międzyosobowego kontaktu opartego na miłości i dobrowolności oraz na "głębokim i uzupełniającym się związku mężczyzny i kobiety" a zarazem jest miejscem spotkania różnych pokoleń, „które pomagają sobie wzajemnie w osiąganiu pełniejszej mądrości życiowej”'. Natomiast instytucjonalny charakter rodziny opiera się na małżeństwie, które to sprawia, że rodzina staje się jednostką prawną, ekonomiczną i społeczną, mającą do wypełnienia określone zadania ${ }^{2}$.

Kościół w swoim nauczaniu, wskazując na znaczenie rodziny jako podstawowej komórki społeczeństwa podkreślał jej wyjątkową pozycję

${ }^{1}$ Karta Praw Rodziny (22 X 1983), w: Posoborowe dokumenty Kościoła katolickiego o matżeństwie i rodzinie, t. 1, red. K. Lubowicki, Kraków 1999, s. 239-250, (dalej skrót KPR ), Wstęp.

${ }^{2}$ L. Dyczewski, Rodzina Karty Praw Rodziny w kontekście społeczeństwa polskiego, w: Rodzina w zmieniającym się społeczeństwie, red. P. Kryczka, Lublin 1997, s. 137-177. 
pośród innych wspólnot. Wyjaśniał przy tym, że rodzina jest społecznością pierwotną i dla człowieka mającą największe znaczenie. Już papież Leon XIII w encyklice Rerum Novarum nauczał, że rodzina „jest starsza od wszelkiego państwa”3 a Pius XII podkreślał, że „rodzina [...] jest podstawową komórką, konstytutywnym elementem społeczności państwowej [...]. Jej pierwszym obowiązkiem jest [...] bezwarunkowe strzeżenie wartości, które rodzinie zapewniają porządek, godność ludzką, zdrowie i szczęście"4. Pierwotność rodziny oraz uznanie jej za prototyp wszelkiej społeczności ludzkiej dostrzeżone zostało przez Jana XXIII w encyklice Pacem in terris, gdzie papież konstatował, że „rodzina - oparta na małżeństwie zawartym dobrowolnie, wyłącznym i nierozerwalnym - jest i musi być uważana za naturalny i podstawowy zalążek społeczeństwa. Należy otoczyć ją troską pod względem ekonomicznym, socjalnym, kulturalnym i moralnym, aby ugruntować jej stabilizację oraz ułatwić wypełnianie jej specyficznego posłannictwa"5. Również nauczanie ostatnich papieży a zwłaszcza św. Jana Pawła II podkreśla, że „rodzina jest pierwszą i ży-

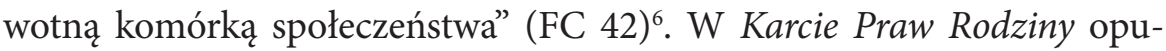
blikowanej 22 października 1983 roku mowa jest o tym, że „rodzina, to związek naturalny, pierwotny w stosunku do państwa czy jakiejkolwiek innej wspólnoty, posiada swoje własne, niezbywalne prawa"7. W niniejszym artykule ukazane zostanie co rodzina wnosi do społeczeństwa i odwrotnie

3 Leon XIII, Encyklika o kwestii socjalnej Rerum Novarum (15 maja 1891), nr 9, w: Encyklika Rerum Novarum, http://www.ptm.rel.pl/czytelnia/dokumenty/dokumentypapieskie/47-leon-xiii/229-encyklika-rerum-novarum.html (dostęp: 1.02.2020).

${ }^{4}$ Pius XII, Przemówienie do ojców (18.09.1951), w: Pius XII. Przemówienie do ojców, http://rodzinakatolicka.pl/pius-xii-przemowienie-do-ojcow/ (dostęp: 1.02.2020); zob. L. Dyczewski, Rodzina Karty Praw Rodziny w kontekście społeczeństwa polskiego, w: Rodzina w zmieniającym się społeczeństwie, red. P. Kryczka, Lublin 1997, s. 141-142.

${ }^{5}$ Jan XXIII, Encyklika o pokoju między wszystkimi narodami opartym na prawdzie, sprawiedliwości, miłości i wolności Pacem in terris (11.04.1963), nr 16, w: Encyklika Pacem in terris, https://opoka.org.pl/biblioteka/W/WP/jan_xxiii/encykliki/pacem_in_terris_11041963.html

${ }^{6}$ Jan Paweł II, Adhortacja apostolska o zadaniach rodziny chrześcijańskiej $w$ świecie współczesnym „Familiaris consortio” (22.11.1981), w: Adhortacje apostolskie Ojca Świętego Jana Pawła II, Kraków 1996, s. 87-208 (odtąd skrót FC).

7 Karta Praw Rodziny (22.10.1983), w: Posoborowe dokumenty Kościoła katolickiego o małżeństwie i rodzinie, t. 1, red. K. Lubowicki, Kraków 1999, s. 239-250, Wstęp. 
jak społeczeństwo troszczy się o rodzinę. Przedstawiona zostanie również w zarysie sytuacja rodziny w Polsce w polityce prorodzinnej po 1989 roku.

\section{RODZINA W SPOŁECZEŃSTWIE, CZYLI CO RODZINA WNOSI DO SPOŁECZEŃSTWA}

Z woli Boga Stwórcy, który ustanowił związek małżeński, rodzina jest pierwszą i żywotną komórką społeczeństwa (DA 11, FC 42). „Jest pierwszą i niezastąpioną szkołą życia społecznego, przykładem oraz bodźcem do szerszych kontaktów społecznych w duchu szacunku, sprawiedliwości, dialogu i miłości” (FC 43). Stanowi ona fundament każdej społeczności, ponieważ zapewnia jej w pierwszej kolejności istnienie biologiczne oraz rozwój duchowy szeroko ujmowany. Jest więc rodzina miejscem biologicznych narodzin człowieka, gdyż to w niej człowiek rodzi się najgodniej i najbardziej po ludzku. Św. Jan Paweł II z wielką mocą podkreślał, że Bóg poprzez rodziców jest wyłącznym dawcą życia. To On ustanowił naturalny sposób poczęcia i narodzin człowieka w rodzinie i przez rodzinę. Stąd też rodzina sytuuje się jako podstawowe środowisko biologicznego i duchowego rozwoju (FC 15). To jej potrzebuje człowiek, aby w pełni stać się człowiekiem. Udowodniono, że pomiędzy potrzebami dziecka a rodziną zachodzi wzajemna korelacja. Tylko rodzina może w pełni zaspokoić ludzkie potrzeby, a przez wychowanie mobilizować ku rozwojowi. Dlatego każda osoba ludzka ma niezbywalne prawo do rodziny ${ }^{8}$.

Wartość rodziny i jej wkład w życie społeczne polega na tym, że dostarcza ona nowych członków społeczeństwu, będąc jego substancjalną podstawą i wpływając na jego jakość. Okazuje się, że zarówno cechy osobowościowe, stan zdrowia biologicznego i psychicznego obywateli najbardziej zależą od uwarunkowań rodzinnych. Bogactwo jakie wnosi rodzina w rozwój społeczeństwa zawiera się w codziennym życiu rodzinnym a zwłaszcza w doświadczeniu komunii i uczestnictwa. Będąc wspólnotą życia i miłości, rodzina jest miejscem szczególnych więzi międzyoso-

8 Jan Paweł II, List do Rodzin „Gratissimam sane” (22 II 1994), w: Listy pasterskie Ojca Świętego Jan Pawła II, Kraków 1997, s. 247-327 (dalej skrót LdR) nr 2; FC 86. 
bowych. Użyte w adhortacji Familiaris consortio określenie communio personarum wyraźnie wskazuje na głębokie, osobowe i międzyosobowe układy społeczne ${ }^{9}$. We wzajemnych stosunkach członkowie wspólnoty rodzinnej „są inspirowani i kierują się prawem bezinteresowności, które szanując i umacniając we wszystkich i w każdym godność osobistą jako jedyną rację wartości, przybiera postać serdecznego otwarcia się, spotkania i dialogu, bezinteresownej gotowości służenia, wielkodusznej służby i głębokiej solidarności” (FC 43). Rodzina tak funkcjonująca staje się wzorem dla szerszych kontaktów społecznych. Stanowi przy tym „kolebkę i najskuteczniejsze narzędzie humanizacji i personalizacji społeczeństwa”, przyczyniając się skutecznie do budowania świata i czyniąc życie coraz bardziej ludzkim, zwłaszcza poprzez przekazywanie cnót i wartości. Wartość jej wyraża się także w tym, że obdarza ona sprawnościami, które rozwijają życie narodu i społeczeństwa. Ponadto jest ona przykładem do tworzenia relacji międzypokoleniowych, przyczyniając się do przełamywania w społeczeństwie anonimowości i chroniąc przed depersonalizacją, umasowieniem oraz pomagając $\mathrm{w}$ pokonywaniu różnych słabości i uzależnień, jak np. przed alkoholizmem czy narkomanią (FC 43).

Do fundamentalnych zadań społecznych rodziny zaliczyć należy oprócz prokreacji i wychowania, w których jest ona nie do zastąpienia

9 Centralnym aspektem teologii małżeństwa i rodziny stało się użycie określenia communio personarum - komunia osób, stanowiące swoistą definicję małżeństwa. Istotą komunii jest miłość a więc małżeństwo to osobowa komunia miłości. Komunia małżeńska wypływa z woli Boga Stwórcy: „stają się dwoje jednym ciałem” (por. Rdz 2, 24). „Ma swoje korzenie w naturalnym uzupełnianiu się mężczyzny i kobiety, i jest wzmocniona przez osobistą wolę małżonków dzielenia całego programu życia, tego, co mają, i tego czym są. Stąd taka komunia jest owocem i znakiem potrzeby głęboko ludzkiej” (FC 19). Z natury swej komunia małżeńska wyklucza poligamię i ma charakter wyłączny i nierozerwalny. W Chrystusie nabiera ona charakteru sakramentalnego. Wymaga jednak od małżonków ducha ofiary, umiejętności akceptacji drugiego takim, jaki jest oraz gotowości do przebaczania i pojednania. Osobowa komunia miłości między małżonkami ze swej natury zakłada otwarcie na życie, czyli rodzenie i wychowanie. Zob. B. Mierzwiński, "Familiaris consortio" jako synteza doktrynalno-pastoralna nauczania Kościoła na temat małżeństwa i rodziny, „Ateneum Kapłańskie” 148 (2007), z. 588, s. 217; J. Grześkowiak, Sakramentalność małżństwa w świetle adhortacji apostolskiej Familiaris consortio Jana Pawła II, w: Małżeństwo i rodzina w świetle nauki Kościoła $i$ współczesnej teologii, red. A.L. Szafrański, Lublin 1985, s. 57-98. 
także zadanie służby społecznej i ukierunkowanie na ubogich. To w rodzinie jej członkowie powinni się angażować w niesienie pomocy sobie nawzajem a jednocześnie innym. W ten sposób rodzina staje się najlepszą szkołą dla młodego pokolenia uczenia się budowania właściwych relacji $\mathrm{z}$ innymi i służby na rzecz potrzebujących (FC 44$)^{10}$.

Istotny wkład rodziny w życie społeczne wyraża się poprzez jej zaangażowanie $\mathrm{w}$ działania polityczne zwłaszcza poprzez interwencje w obronie praw i obowiązków własnych i innych rodzin, szczególnie zaś wtedy, gdy te prawa są łamane bądź podważane. Przestrzenią której nie wolno pominąć i w której rodzina odgrywa istotną rolę jest zadanie tworzenia nowego ładu w wymiarze międzynarodowym (FC 48).

Priorytetowym motywem do zaangażowania się rodzin katolickich $\mathrm{w}$ realizację zadań społecznych i politycznych jest przyjęty sakrament małżeństwa, który uzdalnia oraz zobowiązuje chrześcijańskich małżonków i rodziców do życia odpowiadającego powołaniu ludzi świeckich, a więc do tego by szukali oni Królestwa Bożego, zajmując się sprawami świeckimi i kierując nimi po myśli Bożej. Zadania te wchodzą w zakres królewskiego posłannictwa, w którym małżonkowie uczestniczą na mocy sakramentu małżeństwa i otrzymanej w nim łaski. Każda więc rodzina chrześcijańska powołana jest zgodnie z zamysłem Bożym do składania wobec wszystkich świadectwa oddania się problemom społecznym, zwłaszcza poprzez stawanie w obronie ubogich i zepchniętych na margines. Odpowiedzialność rodziny wobec społeczeństwa nie ogranicza się tylko do zadań społecznych wobec członków własnej rodziny. Rodzina ma bowiem w każdych okolicznościach angażować się w życie społeczne i reagować na potrzeby całego społeczeństwa oraz innych rodzin. Ma ona bowiem pełen tytuł do działań o charakterze społecznym i politycznym, zwłaszcza w dziedzinie tzw. polityki rodzinnej.

\section{SOCJALIZACJA W RODZINIE}

Według nauczania Kościoła posoborowego rodzina jest szkołą bogatszego człowieczeństwa (KDK 52), a przede wszystkim szkołą ról

${ }^{10}$ Cz. Strzeszewski, Katolicka nauka społeczna, Lublin 1994, s. 405-408. 
społecznych (FC 42) i życia społecznego (FC 43). W niej bowiem najwcześniej i najpełniej doświadcza człowiek, że jest istotą społeczną. Społeczny charakter i wspólnotowość stanowią w rodzinie wyraz miłości i szacunku dla godności osobistej i bezinteresowności (FC 43) ${ }^{11}$. Pierwsza socjalizacja czyli wprowadzenie dziecka $\mathrm{w}$ większą grupę społeczną dokonuje się przy jej współudziale, gdyż zapewnia ona nawiązanie trwałych kontaktów $\mathrm{z}$ otoczeniem. Socjalizacja $\mathrm{w}$ rodzinie polega na wprowadzeniu $\mathrm{w} \dot{z} y c i e$ poprzez uczenie zachowań i ról społecznych powszechnie akceptowanych. Do istoty rodziny należy wspomaganie jednostki w dążeniu do własnego dobra i dobra wspólnego. Rodzina mając charakter grupy społecznej ze względu na bezpośrednie, regularne i intymne relacje swych członków ${ }^{12}$ jest jednocześnie instytucją społeczną, opartą na miłości, wolnym wyborze kobiety i mężczyzny połączonych małżeństwem, którzy, odpowiadając wzajemnie za siebie, rodzą i wychowują następne pokolenie w taki sposób, aby ono także rodziło i wychowywało nowe generacje ${ }^{13}$. Szczególna rola rodziny $\mathrm{w}$ procesie socjalizacji wynika $\mathrm{z}$ faktu, że będąc chronologicznie pierwszą, nie napotyka ona żadnych zinternalizowanych sposobów zachowań, systemów wartości, obyczajów czy zwyczajów a na niezapisanej tablicy osobowości dziecka łatwo zapisuje treści, które nie mają żadnej konkurencji.

Doniosłość rodziny jako instytucji socjalizującej wyrasta z jej holistycznego charakteru. Na poziomie socjalizacji, dokonującej się w rodzinie i przez rodzinę, dziecko zdobywa najbardziej podstawowe umiejętności i przyswaja sobie najbardziej potrzebne wzory zachowań, uczy się języka danego społeczeństwa, ról, przyswaja sobie właściwe danemu społeczeństwu aspiracje, sposoby osiągania cenionych wartości i potrzebnej do tego dyscypliny. Wartość rodziny w procesie socjalizacji bardzo mocno

${ }^{11}$ J. Troska, Moralność życia płciowego, małżeńskiego i rodzinnego, Poznań 1998, s. 108 .

12 W. Piwowarski, Przemiany religijnej funkcji rodziny - problematyka i hipotezy, „Studia Warmińskie” 9 (1974), s. 406; F. Adamski, Znaczenie wychowania w rodzinie dla rozwoju osobowego dziecka, w: Miłość-Małżeństwo-Rodzina, red. tegoż, Kraków 1978, s. 366-369; Z. Tyszka, Rodzina w świecie współczesnym a jej znaczenie dla jednostki i społeczeństwa, w: Pedagogika społeczna, red. T. Pilch, I. Lepalczyk, Warszawa 1995, s. 148-149.

${ }^{13}$ L. Dyczewski, Rodzina, społeczeństwo, państwo, Lublin 1994, s. 27. 
podkreśla papież Franciszek, tłumacząc, że to właśnie „rodzina jest pierwszym miejscem, gdzie uczymy się stawać wobec innych, wsłuchiwać się nawzajem, dzielić się, wspierać, szanować, pomagać, żyć jedni z drugimi”. To dzięki rodzinie ma miejsce „wychowanie do umiejętności przebywania poza granicami swego domu"14.

Zaznaczyć należy, że na pierwszym etapie socjalizacji dziecka przez rodzinę najważniejszą rolę odgrywa matka, gdyż to zwykle ona zajmuje się dzieckiem, zaspakajając jego najważniejsze potrzeby. Ona też poświęca dziecku najwięcej czasu. Jej kontakt z nim jest najbardziej naturalny i obejmuje wszystkie wymiary: materialny, psychiczny, duchowy. Matka karmi dziecko, mówi do niego, przewija je, okazuje mu swoje uczucia. Ta forma kontaktu z dzieckiem, kiedy zaczyna ono wiązać z matką zaspokajanie swoich potrzeb ma ogromne znaczenie dla prawidłowego i bezpiecznego rozwoju ${ }^{15}$.

W miarę jak dziecko wzrasta, socjalizująca rola rodziny zaczyna się rozkładać na innych członków: ojca, rodzeństwo i dziadków. Ich udział w socjalizacji zdecydowanie wzrasta i jednocześnie następuje dywersyfikacja ich udziału w zależności od tego, czy dziecko jest chłopcem czy dziewczynką. Około czwartego roku życia dziecko dokonuje pewnego wyboru co do osób, z którymi najchętniej będzie przebywać. Dziewczynki zwykle pozostają przy matce, ucząc się ról pełnionych przez nią, podczas gdy chłopcy swoją uwagę kierują na rolę ojca, zwłaszcza, gdy pełni je on w środowisku rodzinnym. Należy zauważyć, że wraz z wiekiem dzieci wzrasta również socjalizująca rola starszego rodzeństwa. Wtedy to dziecko naśladuje braci, siostry, kopiując ich zachowanie. Swój udział w socjalizacji dziecka w tym okresie mają też nierzadko dziadkowie. Mając na uwadze wielość podmiotów pełniących socjalizującą funkcję w rodzinie, należy podkreślić, że socjalizacja przez rodzinę stanowi zawsze pewną przedłużoną w czasie propozycję - rodziców, starszego rodzeństwa i dziadków - dla podmiotu socjalizowanego - która w żadnym przypadku nie może niszczyć autonomii dziecka. Zaznaczyć należy, że w ramach procesu

14 Franciszek, Posynodalna adhortacja apostolska "Amoris Laetitia” o miłości w rodzinie (19 III 2016), Kraków 2016, nr 266.

15 Zob. Z. Zarembski, W służbie rodziny, w: Ocalić dziedzictwo. Świętemu Janowi Pawłowi II w X rocznice nadania doktoratu honoris causa Uniwersytetu Mikołaja Kopernika w Toruniu, red. J. Bagrowicz, W. Karaszewski, Toruń 2015, s. 239-253. 
socjalizacji przekazywany jest także z pokolenia na pokolenie model rodziny, stwarzając poczucie ciągłości i trwałości życia społecznego. Chociaż rodzina jest najmniejszą komórka społeczną, to jest ona najtrwalszym elementem życia społecznego, swoistym pomostem pomiędzy jednostką a społeczeństwem. Jej rola $\mathrm{w}$ procesie uspołecznienia jednostki jest niezastąpiona ${ }^{16}$. Monopolistyczna i holistyczna rola rodziny $\mathrm{w}$ socjalizacji dziecka ogranicza się w momencie, gdy zaczyna się ono spotykać ze swoimi rówieśnikami aczkolwiek nadal jest obecna aż do momentu jego usamodzielnienia $\operatorname{się}^{17}$.

\section{WZAJEMNE POWIĄZANIA MIĘDZY RODZINĄ A SPOŁECZEŃSTWEM}

Rodzina choć jest najstarszą i podstawową społecznością, to jej struktura, skład osobowy, zasady i wzory wzajemnych stosunków, sposoby wypełniania zadań w ogromnej mierze zależą od społeczeństwa w jakim ona żyje. Wykrycie powiązań pomiędzy społeczeństwem i rodziną jest przedmiotem licznych badań. Stąd też można wyróżnić trzy grupy interpretacji tych powiazań. Jedna mówi, że rodzina zależy od społeczeństwa i jest przez nie całkowicie kształtowana. Takie stanowisko prezentują behawioryści i marksiści. Drugie stanowisko określane jako skrajnie odmienne, głosi, że rodzina ma swój mikroświat i jest niezależna od społeczeństwa. To stanowisko nie było i nie jest powszechne, choć trzeba zaznaczyć, że w swoistej formie przyjmują je ci wszyscy, którzy uważają rodzinę za sprawę czysto prywatną. Najbardziej upowszechnione jest trzecie stanowisko głoszące, że rodzina i społeczeństwo są odrębnymi systemami, tworzącymi układ wzajemnych powiązań i uzależnień. W rezultacie stwierdzić należy, że zarówno społeczeństwo wpływa na rodzinę, jak i rodzina na społeczeństwo. Takie stanowisko znajdujemy w Karcie Praw Rodziny ${ }^{18}$. Również L. Dyczewski podkreśla, że stanowisko to najbardziej weryfikuje

${ }^{16}$ W. Majkowski, Rodzina polska w kontekście nowych uwarunkowań, Kraków 2010, s. 54.

17 Tamże, s. 48-50.

${ }^{18}$ L. Dyczewski, Rodzina Karty Praw Rodziny w kontekście społeczeństwa polskiego, s. 143. 
się w sytuacjach gwałtownych przemian politycznych i gospodarczych każdego społeczeństwa ${ }^{19}$.

Obok wymienionych i opisanych relacji pomiędzy rodziną a społeczeństwem wyróżnić można jeszcze dwa rodzaje wzajemnych powiązań: instytucjonalny i personalny. Pierwszy rodzaj powiązań mający charakter instytucjonalny wyraża się w przepisach, normach, urzędowych relacjach rodziny z zakładem pracy, organizacjami, szkołą czy grupą religijną. Drugi czyli personalny ma swoją podstawę w tym, że te same osoby uczestniczą zarówno w życiu rodzinnym, jak i w życiu społecznym, wnosząc w ten sposób do swojego środowiska rodzinnego wartości, idee, normy, upodobania oraz wzory zachowań i różnego rodzaju wytwory materialne, jakie napotykają w swoich miejscach pracy, organizacjach, na ulicy, w środkach społecznego komunikowania czy centrach kształcenia ${ }^{20}$. Z kolei ich rodzinne układy i formy spędzania czasu wolnego, upodobania oraz wartości rzutują na wszystko to, co członkowie rodzin robią poza domem. Tak więc to wszystko, co ma miejsce w domu znajduje swoje odzwierciedlenie w środowisku pozarodzinnym. Stwierdzono, że jednostki przeżywające np. różne kryzysy rodzinne są bardziej drażliwe w grupach sąsiedzkich a dzieci wychowywane $\mathrm{w}$ postawach egoistycznych są nastawione aspołecznie i są mało użyteczne w życiu społecznym. Natomiast jednostki prawidłowo ukształtowane w rodzinie są pożyteczne społecznie i angażują się w różnorodną działalność, dokonując w życiu społecznym właściwych wyborów i podejmując odpowiedzialne zadania społeczne oraz skutecznie działając na rzecz środowiska.

Na podstawie licznych badań i opracowań stwierdzić należy, że $\mathrm{w}$ rodzinie kształtuje się postawa obywateli i dlatego to rodzina wprowadza młode pokolenia w kulturę, w instytucje i w działania społeczeństwa, pełniąc niejako „rolę odźwiernego", wprowadza ona tym samym młode pokolenie do społeczeństwa. Potwierdzeniem wartości rodziny dla życia społecznego jest nauczanie św. Jana Pawła II, który podkreślał z determinacją, że „przyszłość ludzkości idzie przez rodzinę” (FC 86). W tym kontekście wskazać należy na zasadność podejmowanych wysiłków tych wszystkich, którzy pragną kształtować nowe społeczeństwo, rozpoczynając

19 Tenże, Rodzina, społeczeństwo, państwo s. 121.

20 Tamże, s. 122. 
od troski o rodzinę, zabiegając o jej trwałość i lepsze warunki do pełnienia przez nią przypisanych funkcji. Niezrozumiałe zaś jest postępowanie polityków, ekonomistów czy rządzących, zaniedbujących rodzinę, poprzez podejmowanie decyzji, przyczyniających się do jej zubożenia oraz ustalanie praw naruszających trwałość rodziny ${ }^{21}$.

Zaznaczyć trzeba, że rodzina odgrywa istotną rolę najpierw wewnątrz własnej rodziny, poprzez wzajemną wierność małżonków oraz należyte spełnianie zadań, takich jak rodzenie czy wychowanie dzieci a następnie, przekraczając wymiar prywatności wpływa ona na życie publiczne i decyduje o jego kształcie ${ }^{22}$.

\section{SPOŁECZEŃSTWO W SŁUŻBIE RODZINY}

Rodzina i społeczeństwo mają uzupełniać się $\mathrm{w}$ realizacji funkcji obrony i rozwoju dobra wszystkich ludzi i każdego człowieka. Kompendium nauki społecznej Kościoła naucza, że: „punktem wyjścia dla właściwej i konstruktywnej relacji między rodziną a społeczeństwem jest uznanie podmiotowości i społecznego priorytetu rodziny. Przed społeczeństwem ten wewnętrzny związek stawia również wymaganie niezaniedbywania podstawowego zadania, jakim jest okazywanie rodzinie szacunku i poparcia (FC, 45; LdR 17). Stąd też społeczeństwo, a szczególnie instytucje państwowe - w poszanowaniu wiodącej roli i pierwszeństwa rodziny - powołane są, by zapewniać i popierać prawdziwą tożsamość życia rodzinnego" 23 .

Społeczeństwo powinno w pierwszej kolejności uznać niepodważalną wartość rodziny i jej prawa, zwłaszcza prawo do istnienia i rozwoju oraz pełnienia zadań zarówno wewnętrznych, jak i zewnętrznych. Nie powinno jej pozbawiać zadań, które ona sama czy też we wspólnocie

${ }^{21}$ L. Dyczewski, Rodzina Karty Praw Rodziny w kontekście społeczeństwa polskiego, s. 144.

${ }^{22}$ Papieska Rada do spraw Rodziny, Rodzina a ludzka prokreacja (13.05.2006), w: W trosce o dobro małżeństwa i rodziny. Dokumenty Papieskiej Rady ds. Rodziny, red. M. Brzeziński, t. 1, Lublin 2010, s. 311-363, nr 20.

${ }^{23}$ Papieska Rada Justitia et Pax, Kompendium nauki społecznej Kościoła, Kielce 2005, s. 252. 
z innym rodzinami może spełnić (FC 45). Zarówno więc społeczeństwo, jak i państwo powinno w stosunku do rodziny przestrzegać zasadę pomocniczości. Według której ani państwo ani społeczeństwo nie może i nie powinno pozbawiać rodziny takich zadań, które może ona wypełnić sama lub $\mathrm{w}$ ramach dobrowolnego zrzeszania rodzin. Władze publiczne, mając na uwadze, że dobro rodziny stanowi wartość niezastąpioną i nieodzowną we wspólnocie obywateli winny czynić wszystko celem zabezpieczenia wszelkiej pomocy zwłaszcza gospodarczej, społecznej, pedagogicznej, politycznej czy kulturalnej niezbędnej do tego, aby rodziny mogły w sposób ludzki sprostać swoim odpowiedzialnym zadaniom ${ }^{24}$.

Państwo powinno zapewnić rodzinie prawo do rodzenia dzieci i do ich wychowania a także zagwarantować warunki do godnego życia. Przede wszystkim ustawodawstwo państwowe powinno chronić prawa rodziny i ułatwiać funkcjonowanie rodzin w społeczeństwie. Zadanie to jest szczególnie pilne, gdyż zauważa się, że we współczesnych świeckich systemach prawa brak jest wyraźnego uznania podmiotowości prawnej rodziny, ponieważ najczęściej mówi się w nich o prawach poszczególnych osób: rodziców i dzieci a na ogół nie uznaje się praw rodziny. Zauważyć należy, że również rodzina nie jest uznawana za odrębny podmiot prawa, lecz przedmiot ochrony prawnejej.

W związku z tym, że rodzina żyje i wzrasta w konkretnej społeczności, należy podkreślić, że jej funkcjonowanie uzależnione jest od otaczających ją instytucji, których oddziaływanie może być pozytywne bądź negatywne. Dlatego też ciągle aktualnym wyzwaniem jest ochrona publiczna moralności rodziny, gdyż gwarantuje ona prawidłowe wychowanie i trwałość rodziny. Decydujące znaczenie w tym zakresie przypisać należy środkom społecznego przekazu i treściom w nich podawanych. Afirmujące moralną wartość małżeństwa, rodziny czy posiadania dzieci przyczyniają się one do kreowania pozytywnego modelu małżeństwa i rodziny. Natomiast ośmieszanie w mediach wierności małżeńskiej, funkcji rodzicielskiej i wychowawczej rodziców, a zwłaszcza rodzin wielodzietnych

${ }^{24}$ W. Piwowarski, Podstawowe zasady życia społecznego, w: Słownik katolickiej nauki społecznej, red. tegoż, Warszawa 1993, s. 130-131.

25 J. Stala, Katecheza o małżeństwie i rodzinie w Polsce po Soborze Watykańskim II, Tarnów 2004, s. 118-119. 
zdecydowanie utrudnia funkcjonowanie rodziny, zniekształcając jej obraz a także uderzając w stabilność całego społeczeństwa.

\section{PRAWA RODZINY}

$Z$ racji powołania i swej misji rodzina zasługuje na opiekę ze strony społeczeństwa i państwa. Również zadaniem Kościoła jest towarzyszenie małżonkom i rodzinom, a w podejściu do rodziny istotną rolę przypisać należy wspomnianej już zasadzie pomocniczości, w myśl której każda rodzina jest społecznością autonomiczną i odpowiedzialną za własne zadania. Wyrazem poszanowania autonomii rodziny jest uznanie i poszanowanie przynależących jej praw.

Wydana za pontyfikatu św. Jana Pawła II Karta Praw Rodziny ukazuje katalog praw, należących rodzinie $\mathrm{z}$ racji samej natury rodziny oraz przypomina, że rodzina to podstawowa komórka społeczeństwa, zapewniająca mu egzystencję i rozwój, a zachowanie niezbywalnych praw rodziny to warunek pomyślności państwa i ładu międzynarodowego. Dokument prezentuje fundamentalne prawa rodziny, do których zalicza: prawo każdego człowieka do swobodnego wyboru drogi życiowej, czyli prawo do zawarcia związku małżeńskiego i założenia rodziny albo do pozostawania w stanie bezżennym (art. 1). Osoby, które decydują się pobrać i założyć rodzinę, mają również prawo oczekiwać pomocy ze strony społeczeństwa oraz władz publicznych. Dokument wyraźnie stwierdza, że związki pozamałżeńskie nie mogą być stawiane na równi z małżeństwami zawartymi w sposób właściwy. W katalogu praw na drugim miejscu mowa jest, że małżeństwo może zostać zawarte wyłącznie za dobrowolną i obopólną zgodą, gdzie wykluczony jest wszelki przymus także religijny. Zarówno mężczyzna, jak i kobieta posiadają w małżeństwie tę samą godność i równe prawa. W dalszej kolejności sformułowane zostaje prawo do założenia rodziny i decydowania o czasie narodzin i liczbie dzieci. Dokument wyklucza uciekanie się do antykoncepcji, sterylizacji i aborcji. Stwierdza, że władze nie mają prawa ingerować w planowanie rodziny, a jedynie spieszyć z pomocą zwłaszcza małżeństwom wielodzietnym. Karta Praw Rodziny bierze w obronę ludzkie życie, które od samego początku winno być bezwzględnie otoczone troską i szacunkiem (KPR 
art. 4). Wymienia szereg praw szczegółowych, jak na przykład: prawo do życia, prawo do nienaruszalności fizycznej, prawo do opieki społecznej, do adopcji i inne. $\mathrm{Z}$ prawem rodziny do życia nierozerwalne łączy się niezbywalne pierwszeństwo rodziny do wychowania potomstwa. Rodzice mają prawo do wychowania dzieci zgodnie ze swoimi przekonaniami moralnymi i religijnymi, a także powinni decydować o wyborze szkoły i pod ich kierunkiem ma odbywać się wychowanie w dziedzinie seksualności. Rodzina ma także prawo do ochrony zwłaszcza swoich najmłodszych dzieci przed ujemnymi wpływami i nadużyciami ze strony środków społecznego przekazu ${ }^{26}$.

Karta Praw Rodziny uznaje prawa rodziny do własnego rozwoju (art. 6). Podkreśla przy tym, że władze publiczne winny uznawać i wspierać między innymi godność, intymność i stałość każdej rodziny. Szczególną troską winny być objęte rodziny wielkie. Dokument piętnuje zjawisko rozwodu, gdyż narusza ono trwałość instytucji małżeństwa i rodziny. Każdej rodzinie przysługuje prawo do swobodnego organizowania życia religijnego (art. 7) oraz prawo do wypełniania swej funkcji społecznej i politycznej w budowaniu społeczeństwa (art. 8). Istotne jest także prawo rodziny do zrzeszania się z innymi rodzinami i instytucjami w celu właściwego i gorliwego wypełniania swych zadań. Karta Praw Rodziny z determinacją wskazuje na obowiązki władz publicznych wobec rodzin i jej członków, znajdujących się w różnych sytuacjach życiowych. Mowa jest więc o właściwej polityce rodzinnej w kwestiach prawnych, gospodarczych, społecznych i finansowych. Rodziny mają prawo do systemu społecznego i gospodarczego, w którym organizacja pracy umożliwia członkom rodziny wspólne życie i nie zagraża jedności oraz stabilności rodziny. Chodzi szczególnie o godziwe wynagrodzenie za pracę, wystarczające do założenia i utrzymania rodziny, a także o szacunek wobec kobiety-matki. Rodzina ma także prawo do mieszkania. Również rodziny migrantów mają prawo do ochrony społecznej należnej innym rodzinom ${ }^{27}$.

${ }^{26}$ Zob. Papieska Rada ds. Rodziny, Ludzka płciowość: prawda i znaczenie. Wskazania dla wychowania $w$ rodzinie, Łomianki 1996.

${ }_{27}$ W. Piwowarski, Rodzina w społecznym nauczaniu Kościoła: trwałość i zmiana, w: Rodzina w zmieniającym się społeczeństwie, s. 183-184. 
Stwierdzić należy, że podstawowe prawa rodziny były naruszane w ustrojach totalitarnych a także i w ustrojach demokratycznych. Dlatego Kościół apeluje do władz publicznych w świecie o ich rzeczywiste przestrzeganie. Od tego bowiem zależy nie tylko trwałość rodziny, ale także trwałość społeczeństwa i państwa. Polityka społeczna, której dużą część stanowi polityka rodzinna, w każdym systemie rządów ma podstawowe znaczenie dla ukształtowania personalistycznego ładu społecznego. Prowadzona wadliwie przyczynia się do rozkładu życia społecznego a ostatecznie do podeptania godności i praw człowieka, który jest przede wszystkim „istotą rodzinną" 28 .

Stąd społeczne nauczanie Kościoła poświęca wiele uwagi wspólnocie rodzinnej jako podstawowej komórce społeczeństwa. Kościół broni jej godności i autonomii, miejsca i roli w społeczeństwie oraz zabezpieczenia podstawowych uprawnień, aby lepiej mogła ona wypełniać własne zadania. Już Sobór Watykański II w Dekrecie o apostolstwie świeckich zwracał się do wiernych, ludzi dobrej woli, „by w prawodawstwie cywilnym zabezpieczono bezwzględnie nietykalność tych praw” (DA 11).

\section{RODZINA POLSKA PO 1989 ROKU}

Rzeczywistość, w której przyszło żyć polskim rodzinom po 1989 roku nie należała do łatwych, gdyż Polska do tegoż roku była zniewolona przez systemem komunistyczny, który walczył z Kościołem i wartościami chrześcijańskimi a także z chrześcijańskim modelem rodziny. Również czasy po transformacji systemowej nie służyły dobru instytucji małżeńskiej i rodzinie, ponieważ wiele działań społeczno-politycznych skierowanych zostało przeciwko ochronie życia, wychowaniu i trwałości związku małżeńskiego. Rodzina polska pozbawiona przez lata systematycznej pomocy i skutecznie prowadzonej przez państwo polityki pozostawała osamotniona w swoich zadaniach i narażana była na liczne trudności i zagrożenia w tym także ze strony liberalnych środowisk. Należy jednak podkreślić, że w tych okolicznościach rola Kościoła i instytucji kościelnych nabierała

28 Tamże, s. 184. 
wyjątkowego znaczenia w obronie życia, wychowania młodego pokolenia i wspierania małżonków i rodzin ${ }^{29}$.

W okresie pierwszych lat po 1989 roku najważniejszym zadaniem ówczesnych władz Rzeczypospolitej Polskiej stały się przemiany dotyczące reformy systemu ekonomiczno-społecznego. Skoncentrowanie się na zmianie sposobu nadzoru gospodarki, liberalizacji rynku, sprawiły, że $\mathrm{w}$ tych przemianach nie zawsze dostrzegano małżeństwo i rodzinę. Polityka „rodzinna” sprowadzała się zasadniczo do wysiłków zmierzających do liberalizacji aborcji. Dopiero w latach 1997-2001 dostrzega się poważniejsze symptomy zatroskania o los polskiego małżeństwa i rodziny. Wtedy to bowiem mamy do czynienia $\mathrm{z}$ dokumentami zawierającymi elementy prorodzinnej polityki rządu ${ }^{30}$. Jednak podejmowane próby prowadzenia polityki prorodzinnej spotykały się z ciągłym sprzeciwem niektórych kół poselskich czy rządowych. Tak było z przyjęciem przez rząd Rzeczypospolitej Polskiej 21 lipca 1998 roku „Raportu o sytuacji polskich rodzin” oraz z przyjęciem przez Radę Ministrów dnia 3 listopada 1999 roku „Programu polityki prorodzinnej państwa”. Podobnie było z uchwaleniem ustaw lub zapisów prorodzinnych w sejmie. Tylko w niektórych miastach i województwach istniały i działały zespoły promujące politykę prorodzinną. W 1997 roku większość parlamentarna powołała po raz pierwszy w historii Sejmu Komisję Rodziny, podobna agenda powstała również w Senacie, zaś w rządzie za realizację polityki prorodzinnej wyznaczony został Pełnomocnik Rządu do spraw Rodziny. Program polityki prorodzinnej w szczególny sposób miał zabezpieczyć macierzyństwo, rodzinę i jej godność. Ważną sprawą była przede wszystkim ekonomiczna sytuacja rodziny. Niestety programy nie doczekały się realizacji, gdyż częste zmiany elit rządzących, brak ciągłości decyzji politycznych, odcinanie się od decyzji poprzedników oraz wpływ ideologii partii rządzącej na kierunki proponowanych zmian stawały się przyczyną utrudniającą stworzenie wspólnej polityki rodzinnej. Polska przez lata nie mogła wypracować spójnej polityki rodzinnej a jej charakter był głównie socjalny ${ }^{31}$.

${ }^{29}$ Zob. Z. Zarembski, Troska Kościoła $w$ Polsce o małżeństwo i rodzine po Soborze Watykańskim II. Studium teologicznopastoralne, Toruń 2013, s. 8-10.

${ }^{30}$ J. Stala, Katecheza o małżeństwie i rodzinie w Polsce po Soborze Watykańskim II, s. 108.

${ }^{31}$ J. Puzyna-Krupska, Czy potrzebujemy polityki prorodzinnej? 12 (1060) „Prze- 
W ostatnich latach jesteśmy świadkami pozytywnych zmian na rzecz małżeństwa i rodziny. Sytuacja w Polsce w relacji do rodziny zmieniła się diametralnie w wyniku zwycięstwa Prawa i Sprawiedliwości w wyborach parlamentarnych w 2015 roku. Wtedy to dokonano widocznych zmian w polityce prorodzinnej. Wprowadzono między innymi rządowy program „Rodzina 500 plus”, obejmujący przyznawanie świadczeń na częściowe pokrycie kosztów związanych z zaspokojeniem potrzeb życiowych oraz wychowaniem dziecka ${ }^{32}$. Intensywną działalność podjęło również Ministerstwo Rodziny, Pracy i Polityki Społecznej. Ten kierunek działań stworzył nadzieję na względną stabilizację pozycji małżeństwa i rodziny.

W podsumowaniu podkreślić należy, że między rodziną a społeczeństwem istnieją bardzo ścisłe relacje, które decydują o tym, że społeczeństwo w swej przyszłości jest tym czym aktualnie żyje rodzina. Można powiedzieć, że w rodzinie rodzi się i rozwija spoiwo społeczeństwa czyli przyszły obywatel. Dlatego pomyślność rodziny wpływa w decydujący sposób na pomyślność społeczeństwa i od jej kondycji zależy jego jakość a także przyszłość narodu i państwa. Jednak żeby rodzina przyczyniała się do rozwoju i budowania społeczeństwa należy zapewnić jej ciągłe wsparcie zwłaszcza poprzez przestrzeganie jej praw i zapewnienie właściwych warunków do realizacji jej misji i zadań przez kolejne ekipy rządzących odpowiedzialnych za losy swoich obywateli.

\section{BIBLIOGRAFIA}

Adamski F., Znaczenie wychowania w rodzinie dla rozwoju osobowego dziecka, w: MiłośćMałżeństwo-Rodzina, red. tegoż, Kraków 1978, s. 365-373.

Dyczewski L., Rodzina Karty Praw Rodziny w kontekście społeczeństwa polskiego, w: Rodzina w zmieniającym się społeczeństwie, red. P. Kryczka, Lublin 1997, s. 137-177. Dyczewski L., Rodzina, społeczeństwo, państwo, Lublin 1994.

gląd Powszechny" (2009), s. 31-36; zob. Z. Zarembski, Troska Kościoła w Polsce o matżeństwo i rodzinę po Soborze Watykańskim II. Studium teologicznopastoralne, s. 9-10.

32 Prawo i sprawiedliwość, w: https://pl.wikipedia.org/wiki/Prawo_i_Spra wiedliwo\%C5\%9B\%C4\%87 (dostęp: 25.01.2020). 
Grześkowiak J., Sakramentalność małżeństwa $w$ świetle adhortacji apostolskiej Familiaris consortio Jana Pawła II, w: Małżństwo i rodzina w świetle nauki Kościoła i wspótczesnej teologii, red. A.L. Szafrański, Lublin 1985, s. 57-98.

Franciszek, Posynodalna adhortacja apostolska "Amoris Laetitia” o miłości w rodzinie (19 III 2016), Kraków 2016.

Jan Paweł II, Adhortacja apostolska o zadaniach rodziny chrześcijańskiej w świecie współczesnym „Familiaris consortio” (22 XI 1981), w: Adhortacje apostolskie Ojca Świętego Jana Pawła II, Kraków 1996, s. 87-208.

Jan Paweł II, List do Rodzin „Gratissimam sane” (22 II 1994), w: Listy pasterskie Ojca Świętego Jan Pawła II, Kraków 1997, s. 247-327.

Karta Praw Rodziny (22 X 1983), w: Posoborowe dokumenty Kościoła katolickiego o matżeństwie i rodzinie, t. 1, red. K. Lubowicki, Kraków 1999, s. 239-250.

Majkowski W., Rodzina polska w kontekście nowych uwarunkowań, Kraków 2010.

Mierzwiński B., „Familiaris consortio” jako synteza doktrynalno-pastoralna nauczania Kościoła na temat małżeństwa i rodziny, „Ateneum Kapłańskie” 148 (2007), z. 588, s. 214-221.

Papieska Rada ds. Rodziny, Rodzina a ludzka prokreacja (13.05.2006), w: W trosce o dobro małżeństwa i rodziny. Dokumenty Papieskiej Rady ds. Rodziny, red. M. Brzeziński, t. 1, Lublin 2010, s. 311-363.

Papieska Rada Justitia et Pax, Kompendium nauki społecznej Kościoła, Kielce 2005.

Piwowarski W., Przemiany religijnej funkcji rodziny-problematyka i hipotezy, „Studia Warmińskie" 9 (1974), s. 405-455.

Piwowarski W., Rodzina w społecznym nauczaniu Kościoła: trwałość i zmiana, w: Rodzina w zmieniającym się społeczeństwie, red. P. Kryczka, Lublin 1997, s. 179-186.

Puzyna-Krupska, Czy potrzebujemy polityki prorodzinnej? 12 „Przegląd Powszechny” (2009), s. 20-38.

Troska J., Moralność życia płciowego, małżeńskiego i rodzinnego, Poznań 1998.

Tyszka Z., Rodzina w świecie wspótczesnym a jej znaczenie dla jednostki i społeczeństwa, w: Pedagogika społeczna, red. T. Pilch, I. Lepalczyk, Warszawa 1995, s. 137-154.

Zarembski Z., Troska Kościoła w Polsce o małżeństwo i rodzinę po Soborze Watykańskim II. Studium teologicznopastoralne, Toruń 2013.

Zarembski Z., W służbie rodziny, w: Ocalić dziedzictwo. Świętemu Janowi Pawłowi II $w$ X rocznice nadania doktoratu honoris causa Uniwersytetu Mikołaja Kopernika w Toruniu, red. J. Bagrowicz, W. Karaszewski, Toruń 2015, s. 239-253. 